\title{
Contribution of the root system of vetiver grass towards slope stabilization of the São Francisco River
}

\section{Contribuição do sistema radicular do capim-vetiver para estabilização do talude do Rio São Francisco}

\author{
Lorena Machado ${ }^{1 *}$; Francisco Sandro Rodrigues Holanda ${ }^{2}$; Vanessa Sousa da \\ Silva $^{3}$; Antonio Iury Alves Maranduba ${ }^{4}$; Janisson Bispo Lino ${ }^{4}$
}

\begin{abstract}
The control of soil erosion along the banks of the São Francisco River requires the use of efficient and economically viable strategies. Soil bioengineering techniques may be an alternative to the conventional methods as they provide good soil stabilization by mechanical reinforcement promoted by the roots. The objective of this study was to evaluate the contribution of the root cohesion of vetiver grass (Chrysopogon zizanioides (L.) Roberty) on slope stabilization in erosion control along the right margin of the São Francisco river. Seedlings of vetiver grass were planted in the riverbank of the Lower São Francisco located in Sergipe State, northeast Brazil, and plants were sampled after two years of growth to evaluate the effect of grass on the shear strength of the soil. The monolith and cylinder method was used to collect roots for the evaluation of Root Density (RL), Root Length Density (RLD), Root Area Ratio (RAR), Root Tensile Strength (TR), and Root Cohesion (CR). Data were submitted to analysis of variance $(p<0.05)$, with polynomial regression analysis. The results show that for RL, RLD, and RAR, the layers of soil at depths of $0-0.10 \mathrm{~m}$ had the highest values of $4.84 \mathrm{~kg} \mathrm{~m}^{-3}, 12.45 \mathrm{~km} \mathrm{~m}^{-3}$, $1.66 \%$, respectively. The mean TR was $83 \mathrm{MPa}$ and CR was $528 \mathrm{kPa}$. Vetiver increases shear strength of the soil and slope stabilization.
\end{abstract}

Key words: Chrysopogon zizanioides, soil reinforcement, bank erosion

\section{Resumo}

O controle da erosão marginal do Rio São Francisco requer estratégias eficientes e economicamente viáveis. A técnica de bioengenharia de solos pode ser uma alternativa, visto que proporciona maior estabilização do solo pelo efeito do reforço mecânico promovido pelas raízes das plantas. Esse estudo teve como objetivo avaliar a contribuição à coesão do solo da raiz do capim-vetiver (Chrysopogon zizanioides (L.) Roberty), na estabilidade do talude para controle da erosão da margem direita do Rio São Francisco. Mudas do capim-vetiver foram plantadas no talude da margem direita do Baixo São Francisco no estado de Sergipe, com amostragem das plantas realizada após dois anos do plantio, a fim de avaliar o efeito da gramínea no aumento da resistência ao cisalhamento do solo. Foram utilizadas a metodologia do monólito e o método do cilindro para coleta de raiz, visando à avaliação da Densidade Radicular (DR), Densidade do Comprimento Radicular (DCR), Razão de Raiz por Área (RAR),

${ }^{1}$ Eng $^{\mathrm{a}}$ Agr $^{\mathrm{a}}$, M.e em Agroecossistemas, Dept ${ }^{\mathrm{o}}$ de Engenharia Agronômica, Universidade Federal de Sergipe, UFS, São Cristóvão, SE, Brasil. E-mail: loremachado@globo.com

2 Eng ${ }^{\mathrm{o}}$ Agr $^{\circ}$, Prof. Dr., Dept ${ }^{\circ}$ de Engenharia Agronômica, UFS, São Cristóvão, SE, Brasil. E-mail: fholanda@infonet.com.br

3 Discente do Curso de Graduação em Engenharia Florestal, Dept ${ }^{0}$ de Engenharia Florestal, UFS, São Cristóvão, SE, Brasil. E-mail: vanessa.sousas@hotmail.com

4 Discentes do Curso de Graduação em Engenharia Agronômica, Dept ${ }^{\circ}$ de Engenharia Agronômica, UFS, São Cristóvão, SE, Brasil.E-mail: iubam@hotmail.com; janissonlino@gmail.com

* Author for correspondence 
Resistência de Raízes à Ruptura (TR) e Coesão da Raiz (CR). Os dados foram submetidos à análise de variância $(\mathrm{p}<0,05)$, com análise de regressão polinomial. Os resultados mostram que para DR, DCR e RAR, na camada de 0-0,10 m apresentaram valores mais altos de 4,84 $\mathrm{kg} \mathrm{m}^{-3}, 12,45 \mathrm{~km} \mathrm{~m}^{-3}, 1,66 \%$, respectivamente. O TR médio foi de $83 \mathrm{MPa}$ e o CR de $528 \mathrm{kPa}$. O vetiver favorece o aumento da resistência ao cisalhamento do solo, auxiliando na estabilização de taludes.

Palavras-chave: Chrysopogon zizanioides, reforço do solo, erosão marginal

\section{Introduction}

The São Francisco River has undergone significant changes to its hydrological regime due to the construction of hydroelectric dams. These changes have caused advanced soil erosion of the Lower São Francisco riverbank, starting with the caving of the slope base, which was triggered by low water levels and the associated clearing of riparian vegetation (HOLANDA et al., 2008).

The siltation of the river channel resulting from erosion, whether increased or not by the removal of riparian vegetation, has caused economic, social, and environmental loss to the region and the riverine population. Hence, the revegetation of the riverbank with species that can withstand the ebb and flow of the waves is required in order to reduce soil movement toward the river channel (HOLANDA et al., 2005; OLIVEIRA et al., 2009).

There are several possible methods to control erosion on agricultural soils (SPERANDIO et al., 2012) or to stabilize riverbanks; however, according to Holanda et al. (2007), some techniques have high costs, making their application to the whole area unfeasible. Suleiman et al. (2013) claim that the use of poaceae such as Vetiveria zizanioides to stabilize riverbanks has become increasingly important, particularly as a cost-effective technique that is technically effective and environmentally sustainable, compared with conventional methods. In this context, soil bioengineering can be a viable alternative for controlling bank erosion using live or inert vegetable materials, such as geotextiles, associated or not with rocks, concrete, or metal, thus being environmentally sustainable in the containment of riverbanks with different slopes.
Jones and Hanna (2004) state that soil bioengineering can stabilize the soil and allow living materials to develop a vegetation cover starting the process of ecological succession. Plants are considered one of the most important components in the implementation of these biotechniques. According to Gray and Sotir (1996), roots and stems act as the main structure and are mechanical elements in slope protection systems. The vetiver grass (Chrysopogon zizanioides (L.) Roberty) has been used as a structural component of soil bioengineering techniques as root-based reinforcement in the stabilization of slopes on the right bank of the São Francisco River (HOLANDA et al., 2012).

The vetiver grass is a perennial caespitose grass that grows up to $1.5-2 \mathrm{~m}$ in height, with an extremely fasciculated and deep root system, and is originally from South India. It has dense, hard, and deep roots that are capable of forming a natural clamping system, thus stabilizing embankments (CHONG; CHU, 2007). Due to the aggregating potential of its root system, vetiver grass has been widely used to contain erosion, providing a physicalmechanical consolidation of soil and increasing the shear resistance due to soil-root interactions, thus preventing shallow landslides (GOLDSMITH, 2006).

The effect of roots on slope stabilization improvement has already been recognized in several studies (CAZZUFFI et al., 2006). However, there are still few published reports on the properties of the root system of plants, especially those of vetiver grass. Further studies are needed to improve the understanding of root binding to the soil in order to facilitate their suitability for stabilization 
of river embankments. Gyssels et al. (2005) state that some soil properties such as infiltration rate, moisture content, organic matter content, aggregate stability, and shear strength may be influenced by roots, allowing soil erosion to be controlled. The reinforcing effect promoted by roots associated with slope stability can be evaluated in terms of soil shear strength. To estimate the increase in soil shear strength, provided by roots, models using data from root tensile strength and root distribution are used (WU et al., 1979; DE BAETS et al., 2008).

This study is part of a broad investigation into the behavior of species of the Poaceae botanical family in stabilizing riverbanks. It aimed to evaluate the contribution of root cohesion of the vetiver grass (Chrysopogon zizanioides (L.) Roberty) on slope stability, and thus controlling the erosion of the right bank of the São Francisco River.

\section{Material and Methods}

\section{Study area}

The experimental area is located on the slope of the right bank of the São Francisco River (UTM coordinates $\mathrm{N}=8.868 .789,506$ and $\mathrm{E}=736.583,864$ ) in the city of Amparo de São Francisco, in the state of Sergipe, in soil classified as Fluvisol (Table 1) (HOLANDA, 2008). Seedlings of vetiver grass, from the nursery of the Federal University of Sergipe (UFS), were planted in pits fertilized with $8 \mathrm{~g}$ simple superphosphate plant ${ }^{-1}$, in strands perpendicular to the slope of the bank, spaced $0.9 \mathrm{~m}$ between rows and $0.3 \mathrm{~m}$ between plants in each row.

Table 1. Granulometric composition of Fluvisol from the São Francisco River bank (Amparo de São Francisco - SE).

\begin{tabular}{ccccc}
\hline Depth $(\mathbf{m})$ & Sand $\mathbf{( g ~ k g - 1 )}$ & Silt $\mathbf{( g ~ k g - 1 )}$ & Clay $\mathbf{( g ~ k g - 1 )}$ & Texture \\
\hline $0-0,10$ & 874 & 82,00 & 44,00 & Sandy \\
$0,10-0,20$ & 838 & 98,00 & 64,00 & Sandy \\
$0,20-0,30$ & 755 & 137,00 & 108,00 & Sandy Loam \\
$0,30-0,40$ & 659 & 173,00 & 168,00 & Sandy Loam \\
$0,40-0,50$ & 716 & 167,00 & 117,00 & Loamy Sand \\
\hline
\end{tabular}

Sampling of vetiver grass was performed in August 2013, two years after planting, to evaluate the effect of the grass on soil shear resistance. It was considered important to test adult plants in order to analyze the potential of these specimens to stabilize the slope, in the medium and long term, after being established.

\section{Monolith method}

The monolith method was used to collect roots according to Böhm (1979). The root system of five specimens of vetiver grass was sampled at different depths from $0.50 \mathrm{~m}$ wide, $0.50 \mathrm{~m}$ long, and 0.50 $\mathrm{m}$ high monoliths, amounting to $0.025 \mathrm{dm}^{3}$ in each monolith at different depths. Before initiating the removal of monoliths from the soil, it was necessary to level the surface and the walls of the block. A straight shovel and sharp cleaver were used to assist in cutting and thus obtain the soil portions including the roots at the bottom of each monolith. Samples were taken from layers $0-0.10 ; 0.10-0.20 ; 0.20$ $0.30 ; 0.30-0.40$, and from $0.40-0.50 \mathrm{~m}$, from each vetiver grass specimen. Each monolith was then placed in plastic bags, along with the aerial part of the five sampled plants.

Subsequently, the roots were separated from the soil by washing with a water jet, using sieves with 
a mesh of $1.0 \mathrm{~mm}$ to minimize root loss (BÖHM, 1976). After washing, the roots were placed in paper bags and dried in an oven with forced air circulation at $65^{\circ} \mathrm{C}$ for $72 \mathrm{~h}$. The aerial biomass was also dried at $65^{\circ} \mathrm{C}$ for $72 \mathrm{~h}$.

Thereafter, the weighing of root and shoot biomass took place with an analytical scale, thus determining Root Dry Matter (RDM) and Aerial Dry Matter (ADM). From the RDM, Root Density (RD) could be calculated using Eq. (1), where $M R$ is the mass of roots per class of depth $(\mathrm{kg})$ and $V$ is the volume of soil in each class $\left(\mathrm{m}^{3}\right)$. RD aims to quantify the biomass of roots for each parsed soil depth.

$$
R D=\frac{M_{R}}{V}
$$

To determine the presence of roots in the soil, root length density (RLD) was calculated, and for this purpose, the total measured length of dried roots of each individual layer was required. This was determined with the help of a graduated ruler. The RLD was calculated using Eq. (2), wherein $\mathrm{Cr}$ is the total length of roots per class of depth $(\mathrm{km})$ and $\mathrm{V}$ is the volume of soil $\left(\mathrm{m}^{3}\right)$.

$$
R L D=\frac{C_{R}}{V}
$$

Based on the RLD of each depth class, RAR (Root Area Ratio) was calculated using Eq. (3) to estimate the contribution of the roots to the increase in soil resistance.

$$
R A R=\frac{\frac{R L}{P} a_{i}}{A}
$$

where $R L$ is the total length of roots per class of soil depth $(\mathrm{m}) ; a_{i}$ is the mean cross-sectional area of the root section of a representative plant $\left(\mathrm{m}^{2}\right) ; P$ is the class of soil depth used $(0.10 \mathrm{~m})$; and $A$ is the reference area $\left(\mathrm{m}^{2}\right)$, calculated by the vertical projection of the plant's aerial biomass (DE BAETS et al., 2008).

\section{Cylinder method}

A key step in evaluating the increased root-based resistance is the Root Tensile Strength (TR) test. For this, samples of whole vetiver grass roots were collected using the cylinder method. The cylinders were made of a PVC pipe that was $0.50 \mathrm{~m}$ in height and $0.30 \mathrm{~m}$ in diameter. Undisturbed soil samples containing roots and aerial parts were collected, inserting the cylinder in the soil profile when 25 vetiver grass specimens were removed. Then, the soil portions and the roots from the samples were washed with water jets, using sieves with a mesh of $1.0 \mathrm{~mm}$ in to minimize root loss at the time of washing (BÖHM, 1976).

Among the 25 plants sampled, 50 roots were selected for the root Tensile Strength tests. The following root selection criteria were used: undamaged roots, constant diameter, less than 8 $\mathrm{mm}$ root diameter (maximum diameter at the root that can be tested in the laboratory), and a minimum length of $0.10 \mathrm{~m}$. The roots were stored in alcohol (15\% ethanol) at $4{ }^{\circ} \mathrm{C}$ to maintain viability (DE BAETS et al., 2008).

TR tests were conducted at the Laboratory of Ecophysiology, Federal University of Sergipe(UFS), using a Universal Press. This machine combines the functions of tensile strength generation, load and displacement measuring, and data acquisition. To conduct the tests, the roots were fixed to the gears of the machine with tapping clamps. To circumvent problems in the tests, adjustments were made to the clamps of the equipment to ensure the best grip, avoiding rupturing of the roots in the clamping position. Tests in which the roots broke whilst in the clamping position were considered invalid.

The sample was then subjected to a constant tensile speed of $10 \mathrm{~mm} \times \mathrm{min}^{-1}$. The load cell of the equipment was capable of measuring up to $500 \mathrm{kN}$, 
with an initial force of $1 \mathrm{kN}$. Tensile strength was measured and recorded on a computer connected to the test machine. Equation (3) was used to calculate root Tensile Strength $\left(\mathrm{N} \times \mathrm{mm}^{-1}\right)$ (BISCHETTI et al., 2003).

$$
T R=\frac{F \max }{\pi\left(\frac{D^{2}}{\mathbf{4}}\right)}
$$

where Fmax is the maximum force required for root breakage $(\mathrm{N})$ and $D$ is the mean diameter of the root close to the point of breakage before the application of tensile strength (mm). For this purpose, before the test, the root diameter was measured at three equidistant points using a digital caliper.

\section{Effect of soil reinforcement by vetiver grass roots}

The determination of soil reinforcement provided by vetiver roots was based on the predictions of a perpendicular root reinforcement model using the means of the parameters of the root system from the surface shear and root tensile strength (WALDRON, 1977; MICKOVSKI et al., 2008). In this model, it is assumed that all the roots crossing the shear plane break during the shear process. The magnitude of the reinforcement due to the presence of roots in the soil was determined according to Gray and Sotir (1996), using the following equation:

$$
\mathrm{CR}=1.2 \times T R \times R A R
$$

where CR $\left(\mathrm{N} \mathrm{m}^{-2}\right)$ is Root Cohesion or the increase in shear strength due to the presence of roots in the soil, $T R\left(\mathrm{~N} \mathrm{~m}^{-2}\right)$ is the mean Tensile Strength of the average number of roots with a mean diameter per unit soil area, and $R A R\left(\mathrm{~m}^{2} \mathrm{~m}^{-2}\right)$ is the root area ratio (the ratio between the total root cross sectional area and the total shear area). The CR of specimens collected by Böhm's monolith method (1979) was calculated, taking into account the mean TR for the respective mean diameters of RAR by class of depth.

\section{Statistical Analysis}

Data were subjected to analysis of variance to determine significance at a level of 5\% ( F test). Next, a polynomial regression analysis was performed, adjusting mathematical models and coefficients of determination $\left(\mathrm{R}^{2}\right)$ for each variable. All analyses were performed using the statistical program SISVAR (FERREIRA, 2011).

\section{Results and Discussion}

The total dry matter of five specimens of vetiver grass, sampled by the monolith method, presented maximum values of $2.08 \mathrm{~kg}$ and $0.31 \mathrm{~kg}$ for the shoots and roots, respectively. In contrast, the minimum values were $0.41 \mathrm{~kg}$ for shoots and $0.21 \mathrm{~kg}$ for the root system (Figure 1). For these specimens, the mean ratio between shoots and the root system was 4:1. This indicates that vetiver grass is capable of producing high levels of shoot and root biomass, as suggested by Manoel et al. (2013). The aerial biomass helps to minimize soil loss by providing greater protection to the soil as a result of the strong tillering of the species, thereby reducing the direct impact of raindrops on the soil, whereas root biomass promotes strong anchoring to the ground, which helps to prevent landslides. 
Figure 1. Aerial Dry Matter (ADM) and Root Dry Matter (MSR) of five specimens of vetiver grass.

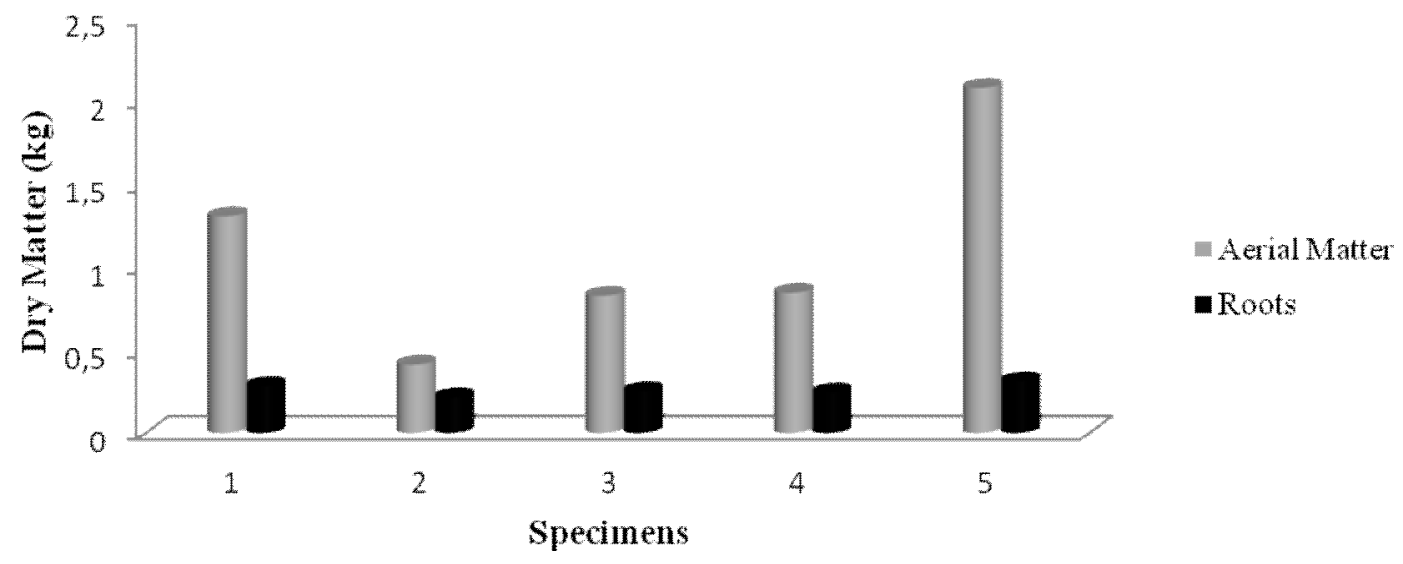

The distribution of root depth was evaluated by the variables Root Density (RD) and Root Length Density (RLD). The biomass of the roots of individual plants analyzed was proportional to root length (Figure II). The change in root density was inversely proportional to depth, presenting a strong negative correlation. $\mathrm{RD}$ showed the best fit to the cubic model $(p<0.05)$ with $\mathrm{R}^{2}=0.9994$, while for the RLD, the model was quadratic $(p<0.01)$ with $\mathrm{R}^{2}=0.9892$ (Figure 2).

Figure 2. Root density (RD) and Root Length Density (RLD) of five specimens of vetiver grass with soil depth.

RD

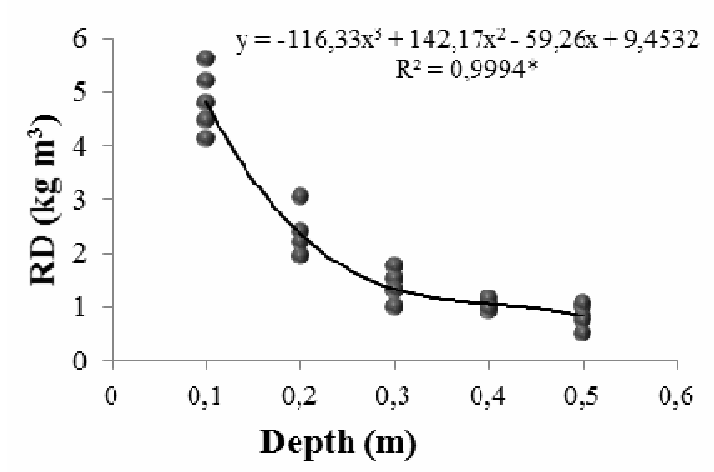

The bulk of RD and RLD were concentrated in the first $0.20 \mathrm{~m}$ above the ground with the $0-0.10 \mathrm{~m}$ layer being the densest. These data corroborate the findings made by De Baets et al. (2007) for all species analyzed. In the $0-0.10 \mathrm{~m}$ layer, the mean values of $\mathrm{RD}$ and RLD were, respectively, $4.84 \mathrm{~kg} \mathrm{~m}^{-3}$ and $12.45 \mathrm{~km} \mathrm{~m}^{-3}$; however, the $0.40-0.50 \mathrm{~m}$ layer had a mean RD of $0.83 \mathrm{~kg} \mathrm{~m}^{-3}$ and a mean RLD of 3.32 $\mathrm{km} \mathrm{m}^{-3}$. It was apparent that there was a reduction in

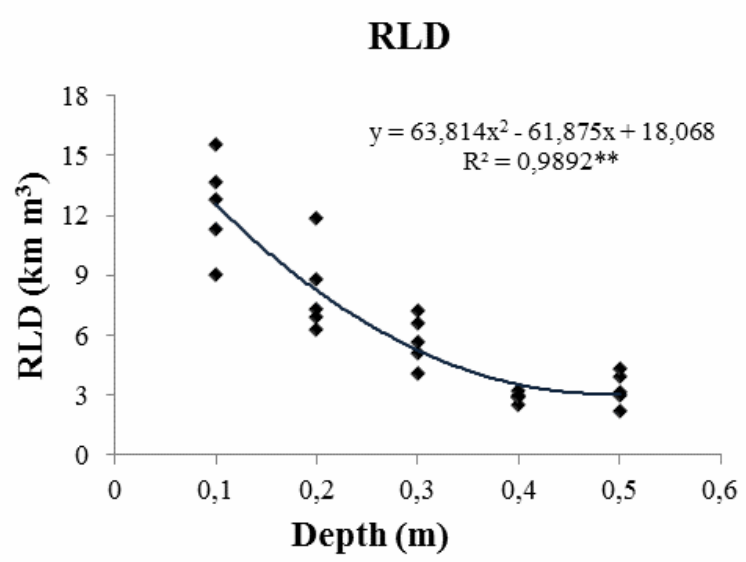

biomass and root length with increasing soil depth, which may have been caused by the lower aeration and nutrient availability in the deeper soil layers, and by the emergence, in depth, of more compacted layers, which would have hindered root penetration and development. This behavior of the soil can be attributed to vertical and horizontal variability of soil layers of different textures and cohesion, which are characteristic of a Fluvisol. 
The root system of vetiver grass is known to reach depths of up to $4 \mathrm{~m}$ (CHONG; CHU, 2007). However, in this study it was noted that the density of roots was reduced, on average, by $82.76 \%$ between the $0-0.1 \mathrm{~m}$ to the $0.4-0.5 \mathrm{~m}$ layer. This suggests that the greatest reinforcement promoted by the root system to the soil occurs in the surface layers where root density is the greatest. Due to this, the shear strength of the embankment's soil, promoted by the roots, decreases with greater depths.

However, even with this decline in root density, the high values found for RD and RLD, especially for the deeper layers, indicated a higher rooting depth of vetiver grass compared to other grasses. De Baets et al. (2007) showed that grass presented a higher density of roots only up to the first $0.25 \mathrm{~m}$ of soil. Because of this dense and deep root system observed in vetiver grass, this grass has become well known for its ability to conserve soil and stabilize slopes in several studies (DONJADEE; TINGSANCHALI, 2013).

To better assess the contribution of the roots to soil strength in relation to depth, the RAR was used. This index represents the soil area that is occupied by the roots, i.e., the concentration of the roots in the soil. Figure III represents the change in the RAR for the five vetiver grass specimens sampled from every $0.10 \mathrm{~m}$ of soil depth. The best-fit regression model was quadratic $(p<0.01)$ showing a strong negative correlation $\left(\mathrm{R}^{2}=0.9717\right)$ of the RAR with soil depth (Figure 3).

Figure 3. Root Area Ratio (RAR) and root Tensile Strength (TR) of vetiver grass with soil depth.

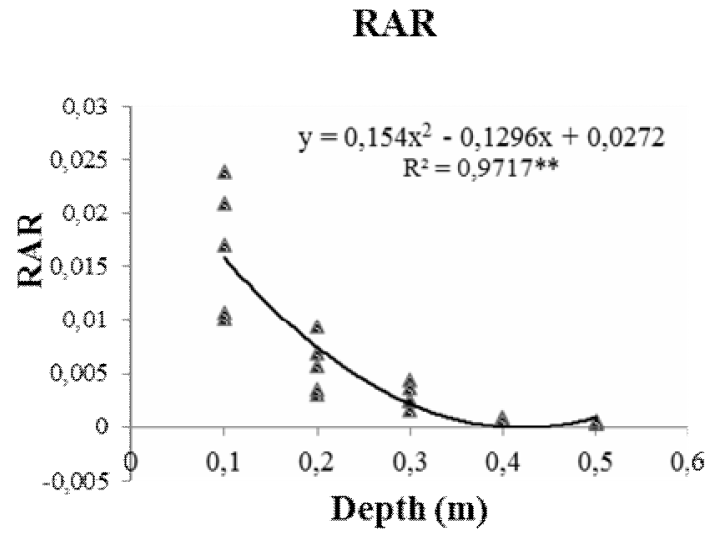

The high mean percentage of RAR $(1.66 \%)$ found for the 0-0.10 m layer when compared to other grasses, can be explained by the extremely dense and fibrous root system of vetiver grass. Abernethy and Rutherfurd (2001) and Bischetti et al. (2005) stated that RAR could reach values close to $1 \%$. This high percentage observed for RAR is another feature that helps to increase the shear strength of the soil, as according to $\mathrm{Wu}$ et al. (1979), shear strength increases with increasing concentration of the roots in the soil.

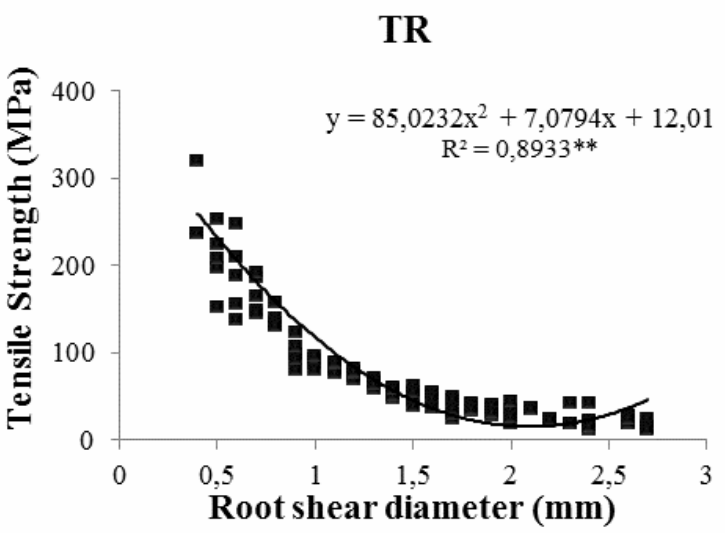

The mean values of RAR in the deeper layers of the soil were significantly $(p<0.01)$ lower than those closer to the surface. This can be explained by the lower density of root length, and by the lower mean cross-sectional area of representative roots found in the deeper layers of the vetiver grass specimens evaluated. Although the mean RAR of $0.04 \%$ for the $0.40-0.50 \mathrm{~m}$ depth is much lower than that of the 0-0.10 $\mathrm{m}$ soil layer, it falls within the range of RAR obtained for all grasses evaluated by De Baets et al. (2008), at a depth of 0.40-0.50 m, and was in many 
cases, higher. This decrease in RAR in the deeper layers confirms that the reinforced shear strength of soil that is promoted by roots decreases with depth.

Figure 3 also shows the TR values, which are essential to evaluate the increase in shear strength through the reinforcement provided by the roots to the soil. Regression analysis showed that $89.33 \%$ of the variation in root tensile strength could be attributed to changes in the diameter at root breakage $(p<0.01)$.

As found in the mechanical testing of TR with vetiver grass performed by Mickovski and Van Beek (2009), the roots evaluated in this study with smaller diameters had a higher tensile strength than the thicker roots. To break roots with less than one millimeter $(\mathrm{mm})$ diameter, a mean tensile strength greater than $100 \mathrm{MPa}$ was used. On the other hand, roots longer than $1 \mathrm{~mm}$ broke with less tensile strength $(<100 \mathrm{MPa})$, reaching a minimum mean tensile strength of $16.4 \mathrm{MPa}$ for $2.7 \mathrm{~mm}$ roots (Figure 3).

Other studies with different species also found that root resistance is very high in thin roots, and that this decreases significantly with increasing diameter (BISCHETTI et al., 2005; TOSI, 2007). According to Genet et al (2005), the variation in tensile strength with the increase in diameter is directly linked to the structure of the root; thinner roots have a high cellulose content. Hence, roots with smaller diameters are stronger and are essential to increase the shear strength of the soil.

The mean TR of $83 \mathrm{MPa}$ obtained during testing of the vetiver grass specimens was very close to the mean resistance values found by Hengchaovanich and Nilaweera (1996) and Cheng et al. (2003) who measured $85 \mathrm{MPa}$ for the same grass. However, the variability in TR may occur due to the age of the root, growth rate, growth orientation by changes in soil moisture content, and soil texture (DE BAETS et al., 2008).
Lower TR values were found by Mickovski and Van Beek (2009). The authors presented values for vetiver TR of $17 \mathrm{MPa}$ to about $2 \mathrm{MPa}$, with root diameters of $0.3 \mathrm{~mm}$ and $1.4 \mathrm{~mm}$, respectively. These low values of tensile strength differ from those observed in the present study; the variable tensile strength varied, on average, from $353 \mathrm{MPa}$ to $16 \mathrm{MPa}$ for roots of $0.4 \mathrm{~mm}$ to $2.7 \mathrm{~mm}$ in diameter, respectively (Figure 3).

This discrepancy may be due to the period in which vetiver grass specimens in those experiments were assessed, which was six months after planting, unlike the assessment of individual plants in the present study, which occurred two years after planting. Barbosa and Lima (2013) reported that increasing time from vetiver grass planting increases the shear resistance parameters of soils.

The presence of roots in the soil tends to increase soil cohesion by increasing soil shear resistance, thereby increasing the surface stability of slopes (Van Beek et al., 2005). The increased shear resistance due to the presence of roots in the soil, also called CR, was calculated as a function of depth classes (Figure 4). The relationship between $\mathrm{CR}$ and depth of soil is represented by a seconddegree polynomial model $(p<0.01)$, with a strong negativ.

In accordance with Figure 4, the relationship between $\mathrm{CR}$ and soil depth is represented by a second-degree polynomial model $(p<0.01)$ with a strong negative correlation $\left(\mathrm{R}^{2}=0.9738\right)$. Similar to other indices analyzed, CR also decreases as the depth increases. This is explained by decreasing TR and RAR in the deeper layers, since CR is directly proportional to these variables. It is worth noting that the result found for $\mathrm{CR}$ confirmed that the higher the root density in the soil, the greater the increase in soil reinforcement against shear force. 
Figure 4. Root cohesion (CR) by soil depth in five vetiver grass specimens.

\section{CR}

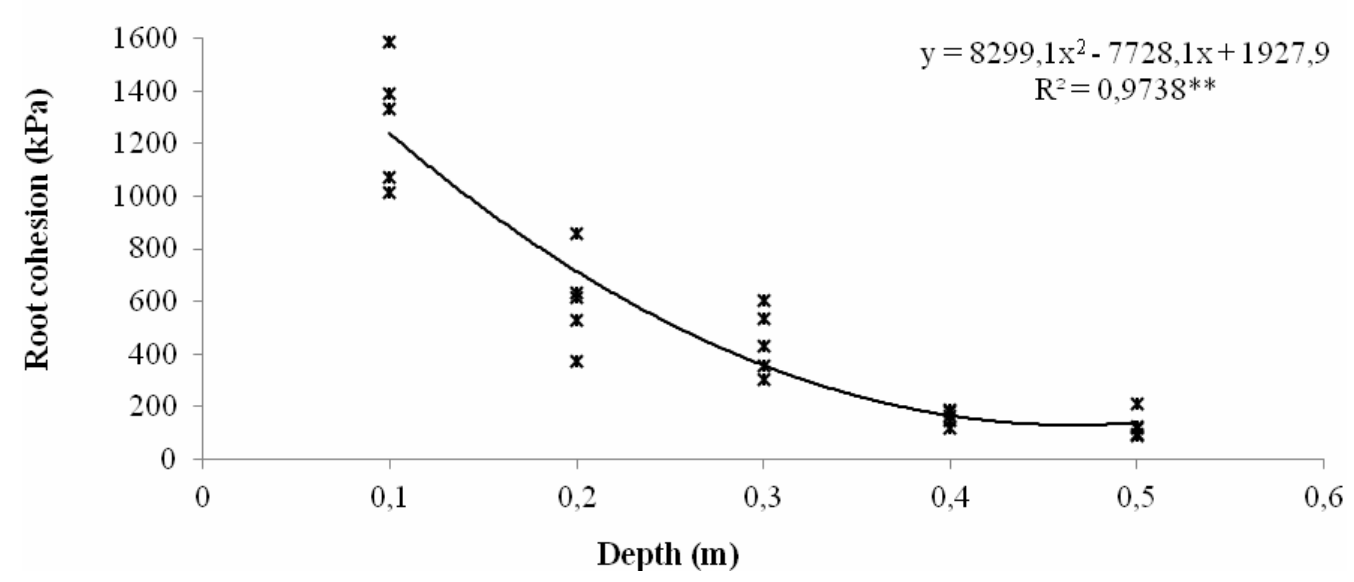

The mean CR found for the first $0.50 \mathrm{~m}$ soil depth of vetiver grass was $528 \mathrm{kPa}$ (Figure 4). Using the same method for calculating CR, De Baets et al. (2008) also found the same tendency with increasing soil depth, but the maximum root reinforcement of the species analyzed by the authors was $304 \mathrm{kPa}$. This variability can be explained by the different characteristics of the species evaluated in the two studies; the vetiver grass showed higher values of TR and RAR.

The result shown in Figure 4 indicates that the vetiver grass contributed to the increase in $\mathrm{CR}$ or soil shear strength of the riverine bank under study from $126 \mathrm{kPa}$ (at a depth of $0.40-0.50 \mathrm{~m}$ ) to 1280 $\mathrm{kPa}(0-0.1 \mathrm{~m})$. Reinforcement of the soil by roots is good evidence that vegetation improves the stability of riverbanks, while the magnitude of the reinforcement, as shown in this study, depends on the morphology of the root system, such as the distribution of roots at different depths, diameters, and tensile strength.

\section{Conclusions}

Fasciculate roots such as the vetiver grass, with proven concentration of small diameter fibers, occupy a large contact surface area, which promotes high tensile strength and hence provides increased shear strength to the soil.

Root Distribution (RD and RLD) presented higher values at the surface due to the higher density of roots in these layers, which is characteristic of species with fasciculate roots.

The high Root Area Ratio (RAR) found for vetiver grass confirms the importance of this gramineae in increasing shear resistance.

The high root Tensile Strength (TR) contributes to the increase in soil resistance to erosion, with emphasis on thinner roots, which have higher TR values.

Root cohesion (CR) increases shear strength in the upper soil layers due to higher root density.

Direct shear tests of this soil with and without revegetation, coupled with deterministic slope stability analyses, are essential to prove the efficient action of vetiver grass suggested by this study.

The use of grasses with dense and fibrous roots is an alternative to the makeup of soil bioengineering techniques for slope stabilization and containment. 


\section{Acknowledgements}

The authors thanks to the Conselho Nacional de Desenvolvimento Científico e Tecnológico (CNPq) on financial support for the development of this research.

\section{References}

ABERNETHY, B.; RUTHERFURD, I. D. The distribution and strength of riparian tree roots in relation to riverbank reinforcement. Hydrological Processes, Malden, v. 15, n. 1, p. 63-79, 2001.

BARBOSA, M. C. R.; LIMA, H. M. Resistência ao cisalhamento de solos e taludes vegetados com capim vetiver. Revista Brasileira de Ciência do Solo, Viçosa, MG, v. 37, n. 1, p. 113-120, 2013.

BISCHETTI, G. B.; BONFANTI, F.; GREPPI, M. Misura della resitenza alla trazione delle radice: apparato sperimentale e metodologica d'analisi. Quaderni di Idronomia Montana, Padova, v. 21, n. 1, p. 349-360, 2003.

BISCHETTI, G.; CHIARADIA, E.; SIMONATO, T.; SPEZIALI, B.; VITALI, B.; VULLO, P.; ZOCCO, A. Root strength and root area ratio of forest species in Lombardy (Northern Italy). Plant and Soil, Rome, v. 278, n.1, p. 11-22, 2005.

BÖHM, W. In situ estimation of root length at natural soil profiles. Journal of Agricultural Science, Cambridge, v. 87, n. 2, p. 365-368, 1976.

Methods of studying root systems. Heidelberg: Springer, 1979. $188 \mathrm{p}$.

CAZZUFFI, D.; CORNEO, A.; CRIPPA, E. Slope stabilisation by perennial "gramineae" in Southern Italy: plant growth and temporal performance. Geotechnical and Geological Engineering, Dordrecht, v. 24, n. 3, p. 429-447, 2006.

CHENG, H.; XIAOJIE, Y.; AIPING, L.; HENG SHENG, F.; MING, W. A Study on the Performance and Mechanism of Soil-reinforcement by Herb Root System. In: THIRD INTERNATIONAL VETIVER CONFERENCE, 3., 2003, Guangzhou. Anais..., Guangzhou: The Vetiver Network, 2003, p. 397-402.

CHONG, C. W.; CHU, L. M. Growth of vetiver grass for cut slope landscaping: effects of container size and watering rate. Urban Forestry and Urban Greening, Jena, v. 6, n. 3, p. 135-141, 2007.

DE BAETS, S.; POESEN, J.; KANPEN, A.; BARBERA, G. G.; NAVARRO, J. A. Root characteristics of representative Mediterranean plant species and their erosion-reducing potential during concentrated runoff. Plant Soil, The Hague, v. 294, n. 1-2, p. 169-183, 2007.

DE BAETS, S.; POESEN, J.; REUBENS, B.; WEMANS, K.; De BAERDEMAEKER, J.; MUYS, B. Root tensile strength and root distribution of typical Mediterranean plant species and their contribution to soil shear strength. Plant Soil, The Hague, v. 305, n. 1-2, p. 207-226, 2008.

DONJADEE, S.; TINGSANCHALI, T. Reduction of runoff and soil loss over steep slopes by using vetiver hedgerow systems. Paddy and Water Environment, Tokyo, v. 11, n. 1-4, p. 572-581, 2013.

FERREIRA, D. F. Sisvar: a computer statistical analysis system. Ciência e Agrotecnologia, Lavras, v. 35, n. 6, p. 1039-1042, 2011.

GENET, M.; STOKES, A.; SALIN, F.; MICKOVSKI, S. B.; FOURCAUD, T.; DUMAIL, J.; VAN BEEK, R. The influence of cellulose content on tensile strength in tree roots. Plant and Soil, Rome, v. 278, n. 1-2, p. 1-9, 2005.

GRAY, D. H.; SOTIR, R. B. Biotechnical and soil bioengineering slope stabilization: a practical guide for erosion control. New York: John Wiley \& Sons, 1996. $378 \mathrm{p}$.

GOLDSMITH, W. Soil strength reinforcement by plants. In: INTERNATIONAL EROSION CONTROL, 2006, Salem. Proceedings... Salem: Proceedings of Annual Conference, 2006. p. 3-18.

GYSSELS, G.; POESEN, J.; BOCHET, E.; LI, Y. Impact of plant roots on the resistance of soils to erosion by water: a review. Progress in Physical Geography, London, v. 29, n. 2, p. 189-217, 2005.

HENGCHAOVANICH, D.; NILAWEERA, N. An assessment of strength properties of vetiver grass roots in relation to slope stabilization. In: THE FIRST INTERNATIONAL CONFERENCE ON VETIVER, 1., 1996. Bangkok. Anais... Bangkok: The Vetiver Network, 1996. p. 87-94.

HOLANDA, F. S. R.; ARAÚJO FILHO, R. N.; LIMA, J. C. B.; ROCHA, I. P. da. Comparison of different containers in the production of seedlings of vetiver grass (Vetiveria zizanioides). Revista Brasileira de Ciências Agrárias, Recife, v. 7, n. 3, p. 439-444, 2012.

HOLANDA, F. S. R.; SANTOS, C. M.; CASADO, A. P. B; BANDEIRA, A. A.; OLIVEIRA, V. S.; FONTES, L. C. S.; ROCHA, I. R.; ARAÚJO-FILHO, R. N.; GÓIS, S. S.; VIEIRA, T. R. S. Análise multitemporal e caracterização dos processos erosivos no Baixo São Francisco sergipano. Revista Brasileira de Geomorfologia, São Paulo, v. 8, n. 2, p. 87-96, 2007. 
HOLANDA, F. S. R.; SANTOS, I. G. da C.; SANTOS, C. M. dos S.; CASADO, A. P. B.; PEDROTTI, A. Riparian fragments affected by bank erosion in the Lower São Francisco River, Northeastern Brazil. Revista Árvore, Viçosa, MG, v. 29, n. 2, p. 148-152, 2005.

HOLANDA, F. S. R.; ROCHA, I. P.; OLIVEIRA, V. $\mathrm{S}$. Estabilização de taludes marginais com técnicas de bioengenharia de solos no Baixo São Francisco. Revista Brasileira de Engenharia Agrícola e Ambiental, Campina Grande, v. 12, n. 6, p. 570-575, 2008.

JONES, K.; HANNA, E. Design and implementation of an ecological engineering approach to coastal restoration at Loyola Beach, Kleberg Country, Texas. Ecological Engineering, Lublin, v. 22, n. 4-5, p. 249-261, 2004.

MANOEL, D. S.; PINTO, L. V. A.; SOUZA, R. X.; OLIVEIRA NETO, O. F.; PEREIRA, M. W. M. Produção de biomassa da gramínea vetiver (Chrysopogon zizanioides (L.) Roberty) em diferentes espaçamentos após 420 dias do plantio. Revista Agrogeoambiental, Pouso Alegre, n. 1, p. 31-34, 2013. Edição Especial.

MICKOVSKI, S. B.; HALLETT, P. D.; BENGOUGH, A.; BRANSBY, M. F.; DAVIES, M. C. R.; SONNENBERG, R. The effect of willow roots on the shear strength of soil. Advances in Geoecology, Catena Verlag, v. 39, n. 1, p. 247-262, 2008.

MICKOVSKI, S. B.; VAN BEEK, L. P. H. Root morphology and effects on soil reinforcement and slope stability of young vetiver (Vetiveria zizanioides) plants grown in semi-arid climate. Plant Soil, The Hague, v. 324, n. 1-2, p. 43-56, 2009.
OLIVEIRA, V. S. de; BARRETO JÚNIOR, E. R.; HOLANDA, F. S. R. Os efeitos naturais, econômicos e sociais da erosão na margem direita do rio São Francisco na sustentabilidade dos agroecossistemas. Revista Agrogeoambiental, Pouso Alegre, v. 1, n. 3, p. 63-72, 2009.

SPERANDIO, H. V.; CECÍLIO, R. A.; CAMPANHARO, W. A.; CARO, C. F. D.; HOLLANDA, M. P. Avaliação da erosão hídrica pela alteração na superfície do solo em diferentes coberturas vegetais de uma sub-bacia hidrográfica no Município de Alegre, ES. Semina: Ciências Agrárias, Londrina, v. 33, n. 4, p. 1411-1418, 2012.

SULEIMAN, M. K.; BHAT, N. R.; JACOB, S. Vetiveria zizanioides plantation for slope stabilization in Kuwait: A case study. Journal of Agriculture and Biodiversity Research, Delta, v. 2, n. 2, p. 44-54, 2013.

TOSI, M. Root tensile strength relationships and their slope stability implications of three shrub species in Northern Apennines (Italy). Geomorphology, Amsterdam, v. 87, n. 4, p. 268-283, 2007.

VAN BEEK, L. P. H.; WINT, J.; CAMMERAAT, L. H.; EDWARDS, J. P. Observation and simulation of root reinforcement on abandoned Mediterranean slopes. Plant and Soil, Rome, v. 278, n. 1-2, p. 55-74, 2005.

WALDRON, L. J. Soil reinforcement by roots: calculation of increased shear resistance from root properties. Soil Science, Madison, v. 132, n. 6, p. 427-435, 1977.

WU, T. H.; McKINNELL, W. P. III; SWANSTON, D. N. Strength of tree roots and landslides on Prince of Wales Island, Alaska. Canadian Geotechnical Journal, Ottawa, v. 16, n. 1, p. 19-33, 1979. 
